USING FREEDOM OF INFORMATION LAWS TO FRUSTRATE ACCOUNTABILITY: TWO CASE STUDIES OF UK BANKING FRAUDS

\title{
Prem Sikka
}

University of Essex

Address for correspondence

Centre for Global Accountability

University of Essex

Colchester, Essex CO4 3SQ, UK.

Email: prems@essex.ac.uk

Tel: +44 (0)1206 873773

Fax: +44 (0)1206 873429

E-mail:prems@essex.ac.uk

February, 2013 


\title{
USING FREEDOM OF INFORMATION LAWS TO FRUSTRATE ACCOUNTABILITY: TWO CASE STUDIES OF UK BANKING FRAUDS
}

\begin{abstract}
Accountability is considered to be central to the functioning of a democratic and informed society. A large volume of literature theorises accountability and explains how it should be and could be deepened. There is a general view that the availability of state held information can enhance possibilities of citizen participation and democratic governance, and check unethical and corrupt behaviour by state and corporate elites. The state held documents can arguably enable citizens to construct a richer account of corporate frauds, accounting/auditing scandals and regulatory failures and call policymakers to account. The neoliberal state has managed the tensions between the public demands for information and the tendency to protect elites from public scrutiny by regularising the flow of information via freedom of information laws. Such laws hold out the possibility of greater information, but also give state officials plenty of discretion to frustrate unwelcome requests. The issues are explored through two case studies relating to banking frauds in the UK. The cases highlight the dynamics of calling the state to account through the freedom of information laws and show that the state apparatus goes to considerable lengths to shield elites from public scrutiny.
\end{abstract}

Keywords: Accountability, Freedom of information, Banks, Frauds, Accountants 
War is Peace. Freedom is Slavery. Ignorance is Strength ${ }^{1}$

\subsection{Introduction}

Accountability is a key concept in contemporary societies and is frequently associated with processes designed to secure trust between decision-makers and affected parties (Sinclair, 1995; Ahrens, 1996). Notions of accountability are deeply embedded in modernity (Hood and Heald, 2007) and considered to be a key to fostering democratic governance and possibilities of greater citizen participation in public policymaking (Habermas, 1976; Hirst, 1994; Young, 2000; Beck, 2003; Castells, 2010). The discourse of accountability is subject to ongoing contestation (Laclau and Mouffe, 1985) and the meanings associated with it are shaped by power and politics. At its heart are concerns about the provision of information and the right to know reasons for particular conducts and hold decision-makers responsible for their actions (Roberts, 1991; Broadbent and Laughlin, 2003). A commonly held view is that every citizen "should know the events and circumstances that concern him, since this is the condition without which he cannot contribute to decisions about them ..." (Simmel, 1950: 337). The demands can relate to wide arena and cover issues such as probity, legality, morality, managerial, programme, performance and policy matters (Stewart, 1984).

The neoliberal state is a key actor in promoting and legitimising practices associated with accountability. Its legitimacy is bolstered by promises of eroding secrecy, enhancing transparency and informing citizens about the conduct of public policy. Therefore, it can be mobilised to investigate corporate collapses, frauds and accounting/auditing failures and inform citizens about the conduct of public policies. However, much of the state generated information remains private and its non-availability thwarts attempts to check on the efficiency, effectiveness and responsiveness of policymakers (Pilger, 1998). In the case of the United Kingdom (UK), most Cabinet papers have remained secret for around 30 years and their release depends on political prejudices. The UK is characterised as a pluralist democracy (Hall and Soskice, 2001), but has a "powerful and persistent culture of secrecy - reflecting the basic assumption that good government is closed government and the public should only be allowed to know what the government decides they should know" (Ponting, 1990: 1). The organised secrecy not only shields politicians and civil servants from parliamentary and public scrutiny, but also protects economic and business elites

${ }^{1}$ George Orwell, Nineteen Eighty-Four, London: Penguin: 1954 (first published in 1949 by Secker and Warburg). 
enmeshed in public policymaking (Cousins, Mitchell and Sikka, 1993). In the absence of public information, people often rely on whistleblowers and conscientious objectors to bring some damning information to the public domain and fuel debates about the accountability of public policymakers (Ponting, 1985).

The dawn of modernity has been accompanied by concerns to "break up the patches of darkness that blocked the light, eliminate the shadowy areas of society, demolish the unlit chambers where arbitrary political acts, monarchical caprice, religious superstitions, tyrannical and priestly plots, epidemics and the illusions of ignorance were fomented" (Foucault, 1980: 153). Such concerns have given rise to the politics of establishing new 'regimes of truth' culminating in freedom of information laws to control the flow of the state held information to citizens. Following persistent criticisms (Bennett, 1985; Vincent 1998; Birkinshaw, 2010), the UK enacted the Freedom of Information Act 2000 (hereafter FOIA) to regulate the release of the state held information to the public. The government claimed that the "Act has profoundly changed the relationship between citizens, and their elected representatives and the media on the one hand, and the Government and public authorities on the other ... made the Executive far more open and accountable. The Act provides a regime for freedom of information which is one of the most open and rigorous in the world". Critics claims that the FOIA may not "limit the deception and deliberate misinformation" (O'Neill, 2002) because the legislation can also be used to legitimise resistance to the release of information (Brooke, 2010).

This paper contributes to the literature on accountability by showing how calls for public accountability are frustrated and resisted by UK government departments. The evidence is presented through two case studies relating to UK banking frauds. The case studies are constructed from direct engagement with the state apparatus through requests made under the UK freedom of information law ${ }^{3}$. Prior research (Sikka and Willmott, 1995; Arnold and Sikka, 2001) provided awareness of some contours of organised secrecy and suggested that the FOIA could be used to secure information. The requests were made in late 2005/early 2006 and were informed by concerns about regulation of banks. For example,

\footnotetext{
2 Hansard, House of Commons Debates, 24 February 2009, col. 153

3 Due to the public nature of many of the documents, the identity of the author cannot be anonymised. In the interest of clarity, later parts of the paper identify various participants by name.
} 
by the late 2005 newspapers carried stories of the bursting of the housing bubble and a possible crisis for some banks. This had echoes of the mid-1970s secondary banking crash, which revealed fraud and audit failures (Reid, 1982). The state managed the crisis by appointing inspectors to investigate the collapses. One of these related to Ramor Investments Limited (previously known as Bryanston Finance), which owned a secondary bank (UK Department of Trade and Industry, 1983). The inspectors' interim report criticised directors and auditors, but the final report remained unpublished (Sikka and Willmott, 1995). The unpublished report had the potential to provide insights into the politics of regulation and was, therefore, the subject of a freedom of information request. The second request also related to concerns about regulation. Despite anti-moneylaundering legislation, UKbased banks have continued to be enable elites to launder illicit funds (US Senate Permanent Subcommittee on Investigations, 2005; UK Africa All Party Parliamentary Group, 2006). These instances had echoes of the operations of the Bank of Credit and Commerce International (BCCl), which pleaded guilty to fraud and money laundering and was closed by the Bank of England in July 1991 (Bingham, 1992). BCCl was considered to be the "world's biggest fraud" (Killick, 1998, p. 151), but its closure has remained shrouded in secrecy. Some gaps in publicly available information have been identified by prior research (Arnold and Sikka, 2001; Mitchell et al., 2001), most notably a report codenamed the "Sandstorm Report", which was prepared by BCCl's auditors Price Waterhouse and enabled the Bank of England to justify closure of BCCl (Bingham, 1992; United States, Senate Committee on Foreign Relations, 1992). The second request, therefore, related to access to the Sandstorm Report.

The research described in this paper was conducted in what may loosely be described as 'action research' (McSweeney, 2000) where inquiry is regarded as a dynamic process and a response to the problems encountered rather than the application of some predetermined set of rules. Such engagements are framed by situated understandings of the material in hand, the importance of the issues, reflexivity of analysis and a range of pragmatic values. The cases reported in this paper involved direct engagement with ministers, lawyers, courts, judges and the state apparatus, with some unexpected outcomes. This paper is organised in four further sections. The first section highlights some complexities and contradictions in the policies of the state, which arguably could enhance and/or frustrate accountability. The second section provides a brief over view of the UK freedom of information legislation. The third section provides the two case studies based to the 
freedom of information requests relating to the collapse of Ramor Investments and the closure of $\mathrm{BCCl}$. The fourth section concludes the paper with some discussion and reflections on the case studies.

\subsection{Accountability and the State}

The public administration of contemporary societies takes place in bureaucratic organisations characterised by rationalisation, calculation, efficiency and predictability (Weber, 1948; 1968). Government departments operate through hierarchical structures and management is primarily based on expert training and written rules. Civil servants are inculcated into the ethos of government departments and their career advancement depends on compliance with formal and informal rules. They advise ministers and policymakers and shape public choices. The resulting written documents have a potential to provide insights into the data used in policymaking, as well as the processes and outcomes involving a variety of political and economic calculations (Hennessy, 2010). Such documents are shaped by the interests already embedded within the system and also by lobbying. Historically, the documents have been accessible to a select few and the state officials have not been obliged to provide the same to the public, unless governments choose otherwise. Much of the freedom for information lobby is driven by the claims that public availability of official documents will enhance democracy and public accountability, curb unethical behaviour and improve public policy-making (Bennett, 1985; Vincent 1998; Birkinshaw, 2010). However, the documents are prepared and held within an organisational context which may not necessarily share the same aspirations and officials may develop diverse strategies for resisting, or obfuscating the release of the information.

The public availability of information may show governments to be responsive to citizens' needs, or can equally demonstrate that they are poorly equipped to deal with the challenges. However, the provision of information per se does not necessarily increase transparency or accountability, as that depends on the context and understanding of events shaping the production and consumption of information. Once the information is widely available and dissected, informed citizens can construct counter accounts to challenge the official narratives and pose unsettling questions. Faced with the likelihood of public exposure, policymakers may seek to shift blame for questionable practices, or may even deny that they were briefed about the possible negative outcomes of their policies. A critical public scrutiny can unsettle the sense of predictability instilled into a bureaucratic system 
and may persuade government officials to withhold information or release it selectively. The secrecy may shield ministers, government departments and elites from scrutiny, but also has the capacity to erode trust and foster a legitimacy crisis (Habermas, 1976). The extent of contradictions and complexities depends on local histories, politics and institutional structures (Ellington, 2011).

Perceptions of risks and uncertainty may be shaped by official documents and analysis, which can make stakeholders aware of the data, policies, reason for policy changes and trajectories for the future. The public availability of information can enable citizens to manage risks and uncertainty by factoring predictability of government policies into their calculations. Consequently, stakeholders may be able to build informed models and be in a position to lobby for/against likely policy changes. The availability of information has the capacity to discipline policymakers because they know that a public scrutiny of their practices can highlight illegal and unethical practices. Arguably, the public provision of information makes government policy predictable and enables citizens and businesses to negotiate uncertainty.

The tendencies toward relative openness are shaped by the competing pressures for legitimacy and the mutual dependence of state and capital. As the ultimate guarantor of capitalism, the state manages the inherent crisis by instituting policies to stabilise or displace the crisis (O'Connor, 1987). These policies may require investment in public goods, bailouts of banks, investigation of corporate collapses and frauds, or promises of releasing official government documents to reassure citizens that the state is accountable to them. However, policies for greater openness or transparency need to have regard for corporate interests. This constraint arises from the nature of neoliberal politics. The neoliberal state is dissuaded from directly owning the means of production and is obliged to rely upon tax revenues levied on profits, wages and consumption, which are largely dependent on private capital (Offe, 1984). Therefore, the state's own survival is dependent on the long-term welfare of capitalism and the two are interdependent for their mutual reproduction and growth. The mutual dependence is intensive in many fields and is highly visible in the defence industry. The state relies upon corporations to secure its position in a hostile nation-state system and in turn the defence industry relies upon the state for its profits. The dependence is not necessarily confined to domestic capital as in a globalised economy capital roams the world in pursuit of profits. For example, the presence of foreign 
banks can stimulate local investment, credit, jobs and financing of exports. These factors then become enmeshed in relations with other states and weigh upon policies of openness which may appease domestic constituencies, but may be seen as hostile by some fractions of capital and international allies. At the same time, the state cannot afford to be seen to be nakedly privileging corporate interests as that can erode its claims of being a neutral adjudicator of social conflicts. Therefore, it may bolster its legitimacy by making some concessions and one of these may be to process demands for a kind of openness which regulates the flow of information to the public.

The state seeks to forge alliances with elites whose expertise is assumed to be helpful in displacing or managing the inherent crisis. This enables some elites to acquire an insider status and a position to influence public policies and shape perceptions of the kind of information which may or may not be released to the public. For example, the UK state has failed to develop in-house structures for investigation of major corporate collapses and thus reassure the public that capitalism is not corrupt. It has been persuaded to see frauds through the lens of accounting and has often delegated the investigation of corporate frauds to partners of major accounting firms (Sikka and Willmott, 1995). This may serve some administrative purposes, but also gives leading accountants easy access to the state apparatus and create possibilities of advancing interpretations of what may or may not be in the public interest, or the documents which may be released to the public.

The notions of transparency and public accountability are mediated through a complex web of relationships enmeshing the state, capital and elites. Elites have numerous opportunities to influence policies and practices relating to the release of the state-held information. For example, corporate funding of political parties enhances corporate access to policymakers and influence policies (Palast, 2002). The privatisation of public enterprises and the reliance on the private sector to provide public goods has also strengthened the links between the state and economic elites (Pierson, 1994). In addition, through revolving-doors, executives from major corporations are frequently seconded to government departments and many former and potential ministers are hired by corporations. Such links have the capacity to undermine the state's aura of being a neutral arbiter of social welfare, but may be countered by practices which greater amount of information in the public domain. 
The links between governments and corporations increasingly blur the distinction between the state and the private sector and fuel the suspicion that the state is captured by big business, or advances the interests of a dominant class. Such perceptions antagonise other fractions of capital and undermine the state's aura of being a neutral arbiter of social welfare. Government policies which enable some selected insiders to have access to information, but deny it to others enhance uncertainty for many citizens and erode confidence in the political system. Such pressures may be managed through the enactment of freedom of information laws to control flow of information.

The calls of greater transparency and information frequently underestimate the capacity of bureaucratic systems to engage in creative or grudging compliance which uses the law to obstruct inquiry and exhaust the energies of inquirers (Hood and Heald, 2006). The documents may be written in an arcane language designed to protect and shield the originators of documents rather than inform the public. Thus transparency may not easily be equated with effective communication. Even the practices designed to enable the public to secure the information are likely to be immersed in legalistic jargon that overwhelms the desire to obtain information. The proponents of freedom of information hope that it will change the culture of government departments, but sceptics argue that "the probability that the adoption of an FOI [Freedom of Information] law will lead to cultural change or improve trust is small. Experience has shown that the governing institution in Westminster systems are particularly resilient and capable of rejecting alien transplantation such as FOI laws, or of developing new routines designed to minimize the disruptive effect of these new laws" (Roberts, 2006:108). The case studies in the later parts of this paper will shed light on some of the practices of government departments and the state apparatus designed to regulate them.

The next section provides a brief overview of the UK's freedom of information legislation.

\subsection{The Freedom of Information Legislation}

The Freedom of Information Act (FOIA) 2000 created a public "right of access" rather than a "right to know" the information held by public authorities. It came into force on 1 January 2005. Within the FOIA, the term 'public authorities' refers to public bodies which exercise public functions. It applies to over 100,000 bodies including government departments, local 
councils, police, hospitals, schools and family doctors. Each of the public authorities is required to have administrative systems to enable it to meet its statutory obligations.

The FOIA grants the right to access to all individuals, including people living abroad, non-UK citizens, lobby groups and commercial organisations. The Act is retrospective and requests can be made for information held before its enactment even if the body is not the originator of the information (UK House of Commons Library, 2004). The requests must be in writing and applicants do not need to give a reason for seeking information. Most requests are free but government departments can refuse requests if the costs of providing the information exceed $£ 600^{4}$. The limit for other public bodies is $£ 450$. All public authorities are expected to respond to a request within 20 working days. The Act is administered by the Information Commissioner's Office, whose mission is to "uphold information rights in the public interest, promoting openness by public bodies and data privacy for individuals ${ }^{5}$.

The concept of "the public interest" is central to the FOIA though the legislation does not define it. It is content to let the concept evolve through practice. In responding to requests for information all public authorities are expected to have regard for the public interest. A guide to accompanying the legislation (Information Commissioner's Office, 2006) provides an indication of the factors which may be considered in assessing whether the public interest is served. These could relate to furthering the understanding of and participation in the public debate of issues of the day, promoting accountability and transparency by public authorities for decisions taken by them, promoting accountability and transparency in the spending of public money, allowing individuals and companies to understand decisions made by public authorities affecting their lives and information affecting public health and public safety.

The public authorities can withhold information by invoking any of the twenty-three public interest exemptions, which are categorised as 'absolute exemptions' and 'qualified exemptions'. 'Absolute exemptions' (Sections 21, 23, 32, 34, 40, 41 and 44 of the FOIA 2000) cover seven distinct areas and apply to matters where there is no legal right of access to the information, or the information relates to security matters, parliamentary privilege, court records, personal information, information provided in confidence or

4 The Freedom of Information and Data Protection (Appropriate Limit and Fees) Regulations 2004.

${ }^{5}$ ICO website - http://www.ico.gov.uk/about_us.aspx; accessed 7 January 2012. 
generally prohibited by law, or the information is available through other means. The second category 'qualified exemptions' covers sixteen distinct areas (Sections 22-24, 26 $31,33,35-38,40,42$ and 43 of the FOIA 2000.). It requires the public authority to consider the balance of public interest lies in releasing and/or withholding the public information. This would depend on the circumstances of each case and may be influenced by common law precedents. Qualified exemptions relate to matters intended for future publication, national security, defence, international relations, relations within the UK, the economy, investigations and proceedings, law enforcement, audit function of public authorities, formulation of government policy, prejudice to effective conduct of public affairs, communications with the monarch and royal family, health and safety, personal information, legal professional privilege and matters of commercial interest. Some of the above may be characterised as 'Class' exemptions and protect all the information in that category. For example, information subject to legal-professional privilege would be protected in its entirety. The remainder may broadly be characterised as Prejudice-based exemptions. A good example of this is the international relations exemption where a public authority could argue that the release of the information could prejudice international relations with one or more states.

The withholding of information may lead to disputes and the FOIA provides a stepped process for resolution. In the first instance, individuals can request an independent internal review (section 50 FOIA 2000), effectively inviting the public authority to reconsider its decision. The internal review is expected to be completed within forty working days and would normally be carried out by individuals not associated with the initial decision to withhold information. If this process does not resolve the dispute then the concerned individuals can invite the Information Commissioner to adjudicate the dispute. If the Commissioner is so persuaded he may investigate the matter and seek explanations from the public authorities and sight of the disputed information. Following an investigation, the Commissioner would publish a Decision Notice to explain his conclusions and make recommendations, which might support the public authority, the complainant or something in-between. He may also praise the public authority for good practice, or admonish it for breaches of the Act and issue enforcement orders.

The parties may dispute the Decision Notice issued by the Information Commissioner and take the matter to the next level. The first port-of-call is the 'Information Rights Tribunal' 
(previously known the Information Tribunal). This is a panel composed of the Tribunal Judge and two other non-legal members, all appointed by the Justice Department. The appeal has to be lodged on an official form within 28 days of the Decision Notice. The parties can choose to have an oral or a paper-based hearing, though the judges can override the choices made by the parties. Both parties can use legal experts to advise them, or can represent themselves in person. In the first instance, cases are heard by the First-tier Tribunal (FTT). Following the FTT decision, the parties may appeal and can seek permission to take matters to a higher court, known as the Upper Tribunal. In principle, depending on the legal issues, matters can reach the Supreme Court. The level of escalation inevitably involves legal ramifications and also the danger that a case may be declared "vexatious" and that costs may be awarded against the parties (Brooke, 2010). The judges can also award costs against either party for unreasonable behaviour.

\subsubsection{Two Case Studies}

This section provides details of two case studies constructed from responses to the freedom of information requests. The first relates to attempts to secure an unpublished report relating to the demise of Ramor Investments Limited (formerly Bryanston Finance Limited), a secondary bank that became subject to a government investigation in 1975. The second relates to attempts to secure the Sandstorm Report, a report which arguably played a major role in the Bank of England's decision to close BCCl.

\subsubsection{Ramor Investments Limited (Formerly Bryanston Finance Limited)}

\subsubsection{Background}

On 12 May 1975, the UK government appointed inspectors to investigate the collapse of Bryanston Finance Limited (on 25 October 1975, it became Ramor Investments Limited). Bryanston was the parent company of National Union Bank Limited, a secondary bank registered in the Bahamas, but operating from London. The Ramor investigation $\operatorname{cost}^{6}$ the UK taxpayer $£ 760,301$. The inspectors submitted an interim report in December 1981, which was published on 22 March 1983 (UK Department of Trade and Industry, 1983). The report provided evidence of fraud and false accounting and concluded that the company chairman "was unwilling and unable to distinguish between the assets of a public company and his own pocket" (p. 392). Another director was described as "a devious and

${ }^{6}$ Hansard, House of Commons Debates, 22 November 1991, col. 347. 
unscrupulous man" engaged in "an obvious fraud" (p.392). The report was also highly critical of Price Waterhouse, Bryanston's auditors. It stated that auditors knew of "false accounting" (p. 278) and should have qualified the accounts "on the grounds that proper books of account had not been kept" (p. 279). Auditors walked away quietly without full disclosure to the incoming auditors. Prior to the annual general meeting called to hear matters relating to auditor resignation Price Waterhouse audit partner Peter Ainger wrote to the chairman of the company to explain how he would avoid answering searching questions (p. 283). Subsequently, a disciplinary panel of the profession reprimanded Price Waterhouse for nine serious errors of judgements and the firm was ordered to pay $£ 273,000$ towards the cost of the hearing (The Times, 25 February 1987). Audit partner Peter Ainger was criticised by name. An interesting aspect of the above episode is that whilst under investigation Price Waterhouse partner Peter Ainger was simultaneously acting as an inspector for the UK government, investigating other frauds and audit failures (UK Department of Trade and Industry, 1981).

The inspectors' final "11 page" report (UK House of Commons Trade and Industry Committee, 1990: 221) was submitted on 11 December 1987, but has remained unpublished. In 1990, in evidence to a House of Commons Trade and Industry Committee hearing, one of the inspectors described the non-publication of the final report as "disturbing". The reasoning given by the Minister for non-publication was that "there has been no public interest in the investigation ... publication at this late stage will serve to revive memories of the disciplinary proceedings taken against Price Waterhouse" (UK House of Commons Trade and Industry Committee, 1990: 221-222). Subsequently, the Minister informed parliament that "Two of those criticised in the Ramor report made representations against publication of the final report. It would not be proper to go into further detail ${ }^{7 "}$. When asked to "make a full statement to the House [of Commons] on his decision not to publish the final report on Ramor Investments", the Minister replied, "No". In a subsequent question he was asked "the date on which he became aware that one its inspectors [Peter Ainger] was being investigated". The Minister replied, "I cannot say".

\subsubsection{The Request for Information}

\footnotetext{
${ }^{7}$ Hansard, House of Commons Debates, 20 July 1993, cols. 131-132.

${ }^{8}$ Hansard, House of Commons Debates, 22 November 1991, col. 343.

${ }^{9}$ Hansard, House of Commons Debates, 29 January 1990, cols. 5-6.
} 
On 18 November 2005, Prem Sikka requested the release of the unpublished Ramor report via an email to the Department of Business Innovation and Skills $\left(\mathrm{DBIS}^{10}\right)$. It also requested the release of the record of meetings, notes and correspondence relating to the report. The DBIS replied, electronically and through post on 20 December 2005, and said that "the report you have requested has not been located and so I must conclude that the DTI no longer holds a copy of the final report to which you refer." The letter was accompanied by some documents which were already in the public domain and formed part of a previously published paper (Sikka and Willmott, 1995). These included extracts from the House of Commons Trade and Industry Committee's inquiry into government commissioned investigations into companies (UK House of Commons Trade and Industry Committee, 1990), texts of some parliamentary questions relating to Ramor Investments and some correspondence between the Minister and Austin Mitchell MP. They provided no clues about the contents of the unpublished (now missing) report, but the letter added that the Department holds

"further information covered by your request, which takes the form of background notes prepared by officials in relation to Parliamentary questions. ... it has been decided not to release this information to you. In doing so, the Department relies on section 35 of the FOIA".

The DBIS invoked 'qualified exemptions' contained in the FOIA to support its position and added that

"The impartiality of the civil service may be undermined if internal advice is routinely made public. Good Government requires good decision making and this needs to be based on the best advice available and a full consideration of all the options. The balance of the public interest in this case lies in withholding this information".

The letter advised that Sikka can ask the DBIS to conduct an internal review and if still dissatisfied, he can then invite the Freedom of Information Commissioner to intervene.

${ }^{10}$ The Department of Business, Innovation and Skills (DBIS) was formed in June 2009. At various times, it has been known as the Department for Business, Enterprise and Regulatory Reform (BERR), the Department for Trade and Industry (DTI) and the Board of Trade (BoT). 
The disappearance of the final Ramor report was puzzling as in 1991 the Minister informed parliament that the papers were held in "store ${ }^{11 "}$. If the report was destroyed then who authorised destruction of the document? On 4 January 2006, Sikka asked the DBIS to undertake an internal review of its decision to withhold the information, including the background notes prepared by officials in relation to Parliamentary Questions, and a copy of any relevant departmental policy document which authorised destruction of documents. The DBIS acknowledged this request on 13th January 2006 and on 10th February promised a substantive reply within the next seven days or so. Eventually, on 3 March 2006, it stated that "the decision to withhold the information you have requested will be reviewed ... by John Alty, The Director General of Fair Markets Group ... target date for competing reviews is 20 days". The letter further added that

"since writing to you on 20 December 2005 some further material (filed under the company's previous name, Bryanston Finance Limited) which may be relevant to your request has come to light. ... This material is being considered as part of the review ... You have asked "when was the report costing $£ 760.301$ destroyed ...". The Department does not hold this information ... I am unable to say with precision when the final report was destroyed. Some material held by the Department in this matter ... was destroyed in 2000 and further material in 2003 under the Department's standard review procedures. The implication in your question is that the Department has destroyed (or mislaid) a document which cost this amount to put together. The fact is that a detailed report was produced and published ${ }^{12 "}$

The above letter was accompanied by the DBIS Policy (two pages consisting of eight paragraphs), dated 22 July 2004, on records destruction, which also applied to the inspectors' reports. Apparently, the Public Records Act 1958 authorised government departments to select records which should be permanently preserved, or transferred to the Public Records Office or elsewhere. The policy document explained that

"Registered files are withdrawn from the Central Files Store by Record Reviewers between eight and twelve years from the date of registration. This is known as the "first review". The files are examined to establish if they are needed for long-term administrative use or may be of historical value. Files retained are then selected for a further review ("second review") are re-examined twenty-five years after registration. About $85 \%$ of DTI files are destroyed at first review; and about $15 \%$ are reviewed for

11 Mr. Austin Mitchell: To ask the Secretary of State for Trade and Industry what representations he has received seeking the publication of the final report on Bryanston. Mr. Redwood: The papers are being recovered from store. I will write to the hon. Member as soon as possible (Hansard, House of Commons Debates, 22 May 1991, col. 477).

12 This is a reference to the interim report which was published in 1983 (UK Department of Trade and Industry, 1983). 
second review at twenty-five years. About $10 \%$ of those files given a second review survive to be deposited at The National Archives".

This above raised some interesting questions. The final report by the Ramor inspectors was submitted to the Department on 11th December 1987 and a request for its release was made on 18th November 2005, some eighteen years later. The Ramor liquidation was not finalised until August $2007^{13}$, which could have given rise of proceedings against some individuals. If the DBIS policy, as described above is applied then someone decided that the report should be destroyed after the first review even though the liquidation, which may have given rise to prosecutions, had not yet been finalised.

On 7th March 2006 the DBIS was asked to provide a list of what it had described as "further material". Its reply of 4th April 2006 did not provide details but said that "... John Alty who you will recall is the Director General will carry out the review you requested". In addition, the reply stated that "we do not hold the information relating to the report being destroyed. ... we are unable to say with complete certainty whether the report was destroyed ... we no longer hold a copy of the final report".

The outcome of the internal review was finally notified to Sikka on 26 June 2006. It review resulted in the release to two redacted items of information, with some information still withheld. With regard to this withheld information, the DBIS sheltered behind the absolute exemptions available under the FOIA by claiming that the release of information would constitute a "breach of confidence" (Section 41) and "contravene one of the principles under the Data Protection Act 1998". The reviewer acknowledged that the Department has a file containing correspondence from the Ramor inspectors, but that following Section 31 FOIA 2000 it could not be released because the "Disclosure of this material would be likely to have an adverse effect on how forthcoming Inspectors might be in the future ...The Department considers it important that inspectors can communicate freely with the Department, and that they can do so in confidence, without fear that these communications will be disclosed to the general public". With the above caveats, two items of "background notes" prepared for the Minister were released. The first item (undated) justified nonpublication of the final report with advice that

${ }^{13}$ A notice by liquidators Baker Tilly appeared in the London Gazette (issue 58425, page 12109) on 20 August 2007. 
${ }^{14}$ It was, and still is, our policy to publish reports on pubic companies $^{15}$, but Ramor ceased to be a public company in 1975 and public interest in Ramor dried up on publication of the interim report in $1983^{16 "}$.

The ministerial adviser(s) referred to correspondence and questions in parliament from Austin Mitchell MP and added that

"There was also the danger that publication of the final report would revive memories of the accountants disciplined and involve them in a degree of "double jeopardy". No honourable members pressed for or against publication of the final report. Two of those criticised in the report argued against publication"

The second (undated) item added that

"Austin Mitchell knows that the accountant inspector in Gilgate, Peter Ainger FCA of Price Waterhouse, was the subject of another inspection in Ramor where he and his firm were criticised and ${ }^{17}$. The final report in Ramor was not published (only the interim report). Austin Mitchell suspects a cover up despite an explanation in earlier correspondence, principally John Redwood's ${ }^{18}$ letter dated 19 September 1991.

Technically, Sikka was entitled to a review of the decision to invoke Section 41 (see above) but was not offered one ${ }^{19}$. The 30 June 2006 review marked the end of the processes internal to the DBIS. The DBIS claimed that the final report is either mislaid or destroyed. It is not possible for any layperson to verify this assertion. Its claims that the publication of the final report "would revive memories of the accountants disciplined" was not considered to be persuasive, especially as some inspectors' reports have been published after disciplinary proceedings against accountants have been finalised (for example, UK

\footnotetext{
${ }^{14}$ Following interventions by the Information Commissioner (see below) the redacted words in this paragraph were released on 29 April 2010. These were "The final report could not be published because it disclosed details of a confidential settlement with Inland Revenue".

${ }^{15}$ Sikka and Willmott (1995) note a number of instances where the government appointed inspectors, but the reports were not published.

${ }^{16}$ This claim is not supported by evidence. For example, the non-publication of the final report was queried by inspectors in the 1990 report by the Treasury Committee (UK House of Commons Trade and Industry Committee, 1990) and since 1990 has also been the subject to questions in parliament and letters to the relevant Ministers.

17 After further correspondence, reviews and interventions by the Information Commissioner, the DBIS revealed that the six redacted words were "and subsequently disciplined by the ICAEW" (letter from the DBIS, 4th June 2009).

${ }^{18} \mathrm{John}$ Redwood was a junior minister at the Department of Trade and Industry from 1989 to 1992.

${ }^{19}$ This point is later pushed by the Information Commissioner.
} 
Department of Trade and Industry, $2001^{20}$ ). The DBIS acknowledged that some information relating to the Ramor investigation existed, but was not willing to identify or release it even though it related to events which occurred over thirty years ago. In the absence of the final report, perhaps the DBIS should release whatever information it held. It was decided to refer the matter to the Information Commissioner.

\subsubsection{The Information Commissioner}

On 2 August 2006, Sikka sent a bundle of papers to the Information Commissioner and invited him to intervene in the dispute. On 23 August 2006, the Commissioner replied stating that "your case has been allocated to one of our case resolution teams who will contact you as soon as possible to explain how your case will be progressed. Due to volume of complaints we are receiving at present it may several months before your hear from us". After follow-up letters (7 December 2006 and 2 September 2007), on 7 September 2007 the case manager at Commissioner's office said that he has raised a number of queries with the DBIS and is awaiting a reply. The Commissioner's office received a reply from the DBIS on 29 November $2007^{21}$. A further letter on 23 January 2008, which was copied to Sikka, inquired about the details of the searches carried out to locate the missing report and also requested that Sikka be given the right to request a review by the DBIS's decision to invoke Section 41 to withhold information and added that "...some of the information is now thirty years old and therefore whilst it may have been confidential and sensitive at the time of the investigation its age may now be a factor which I will have to consider when making a decision. This is particularly the case where the complainant has raised the matter of age with the ICO".

Following the Commissioner's intervention, on 20 February 2008, the DBIS offered Sikka a right to review its decision to invoke Section 41 and withhold information. It also suddenly found additional information. The letter went on:

20 This report related to frauds by media tycoon Robert Maxwell and was published in March 2001. On 2 February 1999, auditors Price Waterhouse were fined $£ 1.2 \mathrm{~m}$ and ordered to pay an additional $£ 2.2 \mathrm{~m}$ in costs for audit failures at Maxwell's empire (BBC News, Record fine for Maxwell accountants, 3 February 1999;

http://news.bbc.co.uk/1/hi/business/270359.stm; accessed 7 January 2012).

${ }^{21}$ Its contents are not known to the author. 
"Over the Christmas 2007 period Companies Division Branch was reviewing a number of papers and amongst them was a synopsis of the final report into Ramor. ... the synopsis was found by chance and had not been overlooked during the earlier search for material ..."

However, the DBIS invoked exemptions available under the FOIA and decided that most of the synopsis would not be released. The redacted synopsis released by the DBI consisted of six paragraphs and about three-quarters of a page in length. The first section dealt with the appointment of the inspectors and did not provide anything of significance. Paragraphs 4 and 5 were withheld in their entirety and parts of paragraph 6 were redacted ${ }^{22}$. The extracts released provided some food for thought by stating that

"....in 1977 they [inspectors] referred to the Department evidence of possible criminal offences. ... In doing so they said that it was difficult to decide whether the conduct they referred to was fraudulent or reckless or merely incompetent. ... In 1979 they referred to the Department evidence suggesting commission of two tax frauds. They decided that it would be wrong to complete their enquiries until the Inland Revenue decided whether action was justified so in 1981 they submitted a substantial interim report which contained all the findings except that they had not investigated fully the tax matters referred to.

....in 1983 disciplinary proceedings were taken by the Institute of Chartered Accountant of England and Wales against firms and individual accountants they had criticised... Price Waterhouse, auditors of Bryanston and two of its subsidiaries ... were reprimanded ... They appealed but lost and ended up being ordered to pay a total of $£ 273,000$ towards the costs. Mr. Ainger, a partner in Price Waterhouse was reprimanded as was secretary of Bryanston, Mr. Fitzhugh. Goodman Jones, a firm which acted for a company which bought Bryanston in 1975, were admonished...

The inspectors conclude their report by pointing out that as a result of the publication of their interim report certain accountancy firms and individual accountants were criticised and ordered to pay costs and this was publicised. The criminal matters they reported to the Department in 1979, by virtue of them being criminal, were not included in their report and hence no disciplinary action was taken against the partners in [REDACTED - FOIA 2000 sections 31(1)(d) and 40(2)] ${ }^{23}$ involved or against that firm and the suspected criminal conduct of all four persons referred to above was not publicised. They say that in their opinion this was unfair. They recommend that copies of their report be sent to the Inland Revenue and to the Institute of Chartered Accountants".

Details and descriptions of the "two tax frauds" were withheld, but the censored text seemed to point the finger at professionals, possibly including accountants, especially as

${ }^{22}$ Some further extracts were released later (see below).

${ }^{23}$ The words in bold letters appear in the document released to Sikka. 
the inspectors asked for the copies of their report to be sent to the Institute of Chartered Accountants.

On 31 March 2008, Sikka asked the DTI to conduct an independent internal review of its decision to withhold some information and the outcome was communicated on 3 June 2008. As regards the allegations of tax fraud, the letter said that the matter was referred to Inland Revenue and,

"following an investigation, the allegations were dealt with by way of a confidential settlement between the Revenue and the taxpayers involved ... I do not consider it would be right to release details of the settlement reached between the Inland Revenue and the tax payers which was confidential"

Without listing any documents, the Reviewer said that some papers are being withheld and also invoked the Data Protection Act to support his decisions, but said that "slightly more" information can now be disclosed. Extracts from the previously withheld paragraph 4 (see above) stated that

"The suspected offences were the evasion of tax totalling $£ 355,000$ by backdating purchase documents to support claims of group tax relief. [Redated FOIA s.31(1)(d), 31(1)(g) and 40(2)] The inspectors report that in 1984 they were informed by the Department that the Inland Revenue were not going to prosecute but had instituted civil proceedings against [Redacted FOIA s.40(2)]. The inspectors decided to delay completion of their report until the civil proceedings, which began in February 1986, were over. In April 1986 they reported that they were informed by the Department that those proceedings had been settled [Redacted FOIA s.31(1)(d) and s.40(2)].

The extracts released from the previously suppressed paragraph 5 said that

"The inspectors criticise the fact that the settlements reached with [Redacted FOIA s40(2)] included in each case an express term whereby all parties agreed to keep the settlements confidential. ... The Inspectors cannot see how this was in the interests of the Revenue or in the public interest. [Redacted FOIA s40(2)] solicitors provided information on the terms of the settlement which forebade the Inspectors to include the information in a published report. The Inspectors refused to submit to these terms because they did not think that it was in the public interest to accept evidence on a confidential or conditional basis. ..."

A number of redacted letters, minutes and handwritten documents were also released to Sikka on 3 June 2008. One of these (document 21) contained a "Note for File", prepared on 25 July 1979 by a civil servant, and stated 
"The inspectors were anxious to see quick action on ... alleging frauds against the Inland Revenue and Mr Ware [a civil servant] said he would endeavour to arrange a meeting with the Inland Revenue ...There was discussion abut whether proceedings should be taken against Hambros Bank under section 167 to elicit information about the ultimate destination of money from the sale of shares by $\quad$ (papers on the file); and against Midland Bank for similar information would be put to Counsel ..."

The correspondence contained in the bundle of information shed some light on the variety of intermediaries involved in various transactions. In one set of documents, the inspectors wrote to the DTI (23 July 1979) to express their concerns about an amount of $£ 67,059.40$ paid to the Midland Bank by Rowe Rudd and Co Limited in respect of the proceeds of shares in one of Bryanston's subsidiaries. These shares were previously held by Midland Bank (Overseas) Nominees Limited for Banque Cantrade AG. The inspectors said that to "complete our investigations, we should, subject to the Counsel's opinion, apply to the Court not only to examine the Secretary of Hambros Bank Limited, but also the relevant officer of Midland Bank Limited to determine the destination of the amount of $£ 67,059.40$ ". In earlier correspondence (for example, 15 August 1977), Midland Bank had said that "at no time have our Company held shares as nominees for Bryanston Finance Limited", but on 23 November 1977, the inspectors sent the Bank a "copy of a Stock Transfer Form, which records the transfer of 375,000 shares ... from the name of Midland Bank (Overseas) Nominees Limited to the names Bryanston Finance Limited". The outcome of this inquiry is not evident from the bundle of papers released.

The internal review resulted in the release of additional information, but the DBIS still withheld unknown amount of information. In any case, large parts of the released information were redacted. So Sikka once again invited (6 July 2008) the Information Commissioner's Office to intervene. Eventually, on 29 April 2009, the case manger at Commissioner's office wrote to say that he has "identified certain matters that require further clarification" and has sought clarification from the DTI. Perhaps, the Commissioner's questions persuaded the DTI reconsider some of its earlier decisions. Following suggestions from the Commissioners, on 4 June 2009, the DTI released 'six words' from a previously redacted document (see footnote17). 
After further correspondence, the Information Commissioner issued a 43 page Decision Notice $^{24}$ on 25 March 2010. It noted that in 2003 the DTI destroyed 33 boxes of material and a file could not be traced though it was recorded in the system as being open (paragraph 33). A further 11 files were destroyed on 11 January $2006^{25}$. The Commissioner concluded (paragraph 35) that "on a balance of probabilities the final [Ramor] report was not held at the time of the request [for information]". The Decision Notice criticised the DBIS for not informing Sikka of his rights and ordered it to release some additional information ${ }^{26}$ (paragraphs 118-120). The DBIS was given 35 days to comply, or lodge an appeal. The DBIS complied and on 29 April 2010 released additional information, including background notes and some correspondence relating to the investigations. The Information Commissioner permitted the DBIS to withhold some of the information because it protected privacy of some individuals even though the information was over thirty-years old and may relate to wrongdoers. On 21 April 2010, Sikka lodged an appeal against the Information Commissioner's decision with the First Tier Tribunal on the basis that all the witheld information should be released. Subsequently, the DBIS was also enjoined and a preliminary hearing, via a telephone conference, with a designated judge to agree the next steps (e.g. dates for exchange of arguments, etc.) was scheduled for 30 June 2010. However, this case coincided with developments in another case (see below) and Sikka, who had no legal representations, felt that he could not simultaneously take on two government departments and on 29 June 2010 withdrew his appeal.

\subsubsection{Bank of Credit and Commerce International Limited (BCCl)}

\subsubsection{Background}

$\mathrm{BCCl}$ began life in Pakistan but eventually expanded with offices in London, Luxembourg, Lebanon, Dubai, Sharjah and Abu Dhabi. By the mid-1980s, it had assets of US\$22 billion and operated from 73 countries. It was regulated by the Bank of England. On 5 July 1991, following evidence of fraud, kickbacks, money laundering and racketeering, the Bank of England closed BCCl's operations (United States Senate Foreign Relations Subcommittee

\footnotetext{
${ }^{24}$ This is available at http://www.ico.gov.uk/upload/documents/decisionnotices/2010/fs_50129139.pdf

25 The request for information was made on 18 November 2005.

${ }^{26}$ This is listed in Appendix C accompanying the Decision Notice. However, Appendix C was neither sent to the complainant nor made public because at the date of the DN the information in Appendix $\mathrm{C}$ is disputed information, which in principle can be the subject of litigation, and is thus treated as confidential.
} 
on Narcotics, 1991; Bingham, 1992; United States Senate Committee on Foreign Relations, 1992). At the time of its closure $\mathrm{BCCl}$ had some 1.4 million depositors across the world. The creditors' collective losses were estimated to be over US $\$ 10$ billion and around 14,000 people worldwide lost their jobs ${ }^{27}$. The closure of $\mathrm{BCCl}$ prompted critical reports by US Senate Committees (for example, United States Senate Foreign Relations Subcommittee on Narcotics, 1991; United States Senate Committee on Foreign Relations, 1992), together with the release of some hitherto secret files ${ }^{28}$ held by the Central Intelligence Agency (CIA). The US Senate Committee concluded that

"BCCl's British auditors, Abu Dhabi owners, and British regulators, had ... become BCCl's partners, not in crime, but in coverup. The goal was not to ignore BCCl's wrongdoing, but to prevent disclosure of the wrongdoing from closing the bank. ... the Bank of England, Price Waterhouse, Abu Dhabi and BCCl had together colluded to deprive the public of the information necessary for them to reach any reasonable judgment on the matter, because the alternative would have been BCCl's collapse (United States Senate Committee on Foreign Relations, 1992:. 276).

The US Senate report had sight of the "Sandstorm Report"29", which provided

"An insider's account of BCCl's fraud created by BCCl's own auditors, Price Waterhouse, and provided to the Bank of England dated June 22, 1991, the "Sandstorm Report," was the final evidence that lead to the shutdown of $\mathrm{BCCl}$ globally on July 5,1991 . That draft report, based on a review of banking records from several countries and interviews carried out through the spring of 1991, found evidence of "widespread fraud and manipulation," at $\mathrm{BCCl}$, reflecting "the general scale and complexity of the deceptions which have undoubtedly taken place over many years" (United States Senate Committee on Foreign Relations, 1992: 52).

Some aspects of the Sandstorm Report were leaked in the UK press and the Sunday Times (21 July 1991, pages 1 and 20) claimed that a copy "was sent to Sheikh Zayed, the ruler of Abu Dhabi and owner of BCCl".

The $\mathrm{BCCl}$ closure was followed by some prosecutions ${ }^{30}$, but unlike other banking frauds of the late twentieth-century (for example, UK Department of Trade and Industry, 1976, 1977,

${ }^{27}$ Hansard, House of Commons Debates, 22 October 1992, cols. 574-89.

${ }^{28}$ This is not to suggest that the US is somehow gloriously open. Rather it has a different history and politics (for a discussion, see Barone, 2006).

${ }_{29}$ In March 1991, the Bank of England asked BCCl auditors Price Waterhouse to prepare the report under Section 41 of the Banking Act 1987. An interim report was submitted on 22 June 1991. It was not finalised. 
1983; Board of Banking Supervision, 1995) the UK government did not appoint inspectors to investigate the frauds. As a way of managing the crisis, on 19 July 1991, it appointed Lord Justice Bingham to conduct an inquiry "into the supervision of $\mathrm{BCCl}$ under the Banking Acts; to consider whether the action taken by all the UK authorities was appropriate and timely; and to make recommendations" (Bingham, 1992, page iii). The Prime Minister said that "The conclusion of the inquiry will be made public ${ }^{31 "}$. On 22 October 1992, the Chancellor of the Exchequer told parliament that the government has decided to publish the report "... unamended and in full but without the supporting appendices ${ }^{32}$ ". The appendices are thought to have contained extracts from the Sandstorm Report. The Bingham report briefly referred to the Sandstorm Report (pages 138 to 140) and considered its contents as "fairly damning" and "devastating" (para 2.447 and 2.448), but it remained secret. A number of parliamentary committees examined the BCCl closure (for example, UK House of Commons Treasury and Civil Service Select Committee, 1991, 1992a, 1992b, 1992c), but none were given sight of the Sandstorm Report.

The US Senate Committee on Foreign Affairs had access to both the full and a censored version of the Sandstorm Report. It stated that the

"report has been provided to the Subcommittee solely in a heavily censured form by the Federal Reserve at the insistence of the Bank of England, which forbid the Federal Reserve from providing a clean copy of the report to the Congress on the ostensible ground that to do so would violate British bank secrecy and confidentiality laws" (United States Senate Committee on Foreign Relations, 1992: 53).

Subsequently, the Senate Committee added that it

"obtained an uncensored version of the report from a former $\mathrm{BCCl}$ official, which revealed criminality on an even wider scale than that set forth in the censured version" (United States Senate Committee on Foreign Relations, 1992: 53).

In accordance with the US freedom of information laws, the censored copy of the Sandstorm Report was deposited in the US Congress Library. In accordance with the US Depository Library Act 1962, it was also made available to 1,250 regional libraries. In 1999, as part of research into a paper on BCCI (Arnold and Sikka, 2001), Professor Patricia

30 The Guardian, Files closed on BCCl banking scandal, 17 May 2012 (http://www.guardian.co.uk/business/2012/may/17/files-close-bcci-banking-scandal; accessed 20 May 2012).

${ }^{31}$ Hansard, House of Commons Debates, 22 July 1991, col. 755, 761.

32 Hansard, House of Commons Debates, 22 October 1992, cols 574-89 
Arnold found the censored version of the Sandstorm Report, together with extracts of Price Waterhouse audit working papers, in a public library in the US state of Wisconsin. The documents were photocopied and mailed to Sikka who placed a scanned copy on the internet $^{33}$. The UK government was informed and invited to make a statement. It declined ${ }^{34}$.

In view of the public availability of some parts of the Sandstorm Report, the UK Prime Minister $^{35}$ and the Chancellor ${ }^{36}$ were urged to publish the full version, or at least equivalent to that found in the US Congress Library. They declined. The standard response was that the contents are covered by the confidentiality provisions of Part V of the Banking Act 1987. The Prime Minister's letter of 16 June 1999 said that

“... certain US authorities were provided with copies (with some information deleted in certain cases) and the copies were not marked "confidential", they were provided under conditions of confidentiality"

A further letter, dated 2 August 1999, said that

“... copies of the draft report (in unredacted or redacted form) were made available to the US authorities on the basis that confidentiality would be protected. It was, however, recognised that if information was required by Congress (eg the House Banking Committee) it would have to be provided. However, even then the Committee would protect the confidential information or parts of it".

The Treasury Minister, replying (letter dated 8 December 1999) on behalf of the Prime Minister, said that the report would not be released even under future freedom of information laws.

${ }^{33}$ See http://visar.csustan.edu/aaba/Sandstorm1.pdf and http://visar.csustan.edu/aaba/Sandstorm2.pdf

${ }_{34} \mathrm{Mr}$. Mitchell: To ask the Chancellor of the Exchequer if he will (a) make a statement on the publication on the website of the Association for Accountancy and Business Affairs of the Sandstorm report by Price Waterhouse on $\mathrm{BCCl}$ and (b) place a copy of the report in the Library. Ms Hewitt: No (Hansard, House of Commons Debates, 14 June 1999, col. 28). The Association for Accountancy and Business Affairs (AABA) is a not-for-profit organisation registered in the UK. Prem Sikka is its director.

35 For example, letters from Austin Mitchell MP on 26 October 1998, 22 April 1999, 22 June 1999, 14 October 1999; replies on 10 December 1998, 16 June 1999, 2 August 1999, 9 December 1999.

${ }^{36}$ For example, letters from Austin Mitchell MP on 17 June, 23 June 1998, 20 January 2000; replies dated 22 July 1998, 9 December 1999. 
The above suggests that versions of the Sandstorm Report were released by the UK government to a selected number of individuals and organizations. At the same time the UK government steadfastly refused to release the Sandstorm Report, either in full or in part, to the public. The implementation of the FOIA created possibilities for securing the full Sandstorm Report.

\subsubsection{The Request for Information}

There had not been a statement by any government official stating the exact length of the Sandstorm Report. Under the circumstances, rather than asking the UK Treasury to fill-in a series of blanks in the version held in the US Congress Library, and on the internet, a request for the full report was made on 3rd January 2006. An email from Prem Sikka asked the Treasury Department to provide three things: a) A copy of the Sandstorm Report; b) correspondence relating to $\mathrm{BCCl}$ audits, which is likely to be between the Treasury Department, Bank of England, the Institute of Chartered Accountants in England and Wales (ICAEW) and Price Waterhouse; and c) $\mathrm{BCCl}$ related correspondence between the US Senate Committee on Foreign Relations and the UK Treasury Department. On 1st February 2006, the Treasury replied stating that it holds the information requested, but declined to process the request because would cost more than $£ 600$, a limit specified by section 12 of the FOIA.

The Treasury response was disappointing, but at least confirmed the existence of the requested information. In principle, it appeared that Section 12 constraints could be negotiated by making multiple requests over a period of time. Therefore, on 8 March 2006 a copy of the Sandstorm Report only was requested. A Treasury official replied on 10 April 2006 and stated that "we have not yet reached a decision on where the balance of public interest lies ... it will take up to an additional 20 working days to take a decision ....we intend to respond by 11th May 2006". A further letter of 2nd June 2006 promised a reply "by the end of the month". As nothing further was heard reminders were sent on 5th and 24th October. In an email dated 26th October 2006, the Treasury case manager replied that

"As you may well be aware, the ongoing BCCI litigation only concluded recently. Due to the complexity of the case and the report we have had to consult third parties to ensure that we meet the significant duties placed upon us by the Data Protection Act and the Freedom of Information Act. ... we are very close to a conclusion and expect to reply formally to your request within a week or two" 
The Treasury reply hinted that it may withhold information by shelter behind one or more of the exemptions permitted by the FOIA. On 26 October 2006, Sikka reminded the Treasury that " $\mathrm{BCCl}$ liquidators, Deloitte \& Touche, dropped the case ${ }^{37}$ in November 2005, long before the request for information and financial settlement was reached in early June $2006^{38}$ ". Despite the Treasury promise of a reply "within a week or two" nothing further was heard. So a reminder was sent on 16 February 2007.

On 27 February 2007, the lack of response from the Treasury was raised in the House of Commons by Austin Mitchell MP and the Chancellor said that

"Professor Sikka's request has entailed the careful examination of several complex issues. I understand that officials expect to be in a position to respond very shortly ${ }^{39,}$.

Following the above exchange, Sikka wrote to the Minister on 28th February 2007 and invited him to shed some light on what he termed "complex issues". Eventually, a four page reply was received from the Treasury on 28 March 2007. It raised five major issues and these are explained below.

Firstly, the Treasury found the redacted version of the Sandstorm Report on the internet (placed there by Sikka) and invoked Section 21 of the FOIA to say that it is not required to provide the parts already in the public domain. The Treasury compared the internet version with the unredacted version in its possession and found a number of typing/scanning errors and sent in a list of corrections. Secondly, the Treasury was unwilling to provide a complete version of the report but it knew that the Report (in unredacted form) was included in the documents filed by the Bank of England in the proceedings brought against the Bank by the liquidators of $\mathrm{BCCl}$. The letter added that

"Rule 5.40(2) of the Civil Procedure Rules allows a person to make an application to the Court for copies of certain documents that have been filed with the Court in legal

\footnotetext{
${ }^{37}$ Bank of England press release, BCCI Liquidators Withdraw Case Against the Bank of England, 2 November 2005

(http://www.bankofengland.co.uk/publications/news/2005/111.htm; accessed on 4 January 2012). The liquidator, Deloitte \& Touche, had accused the Bank of England and 22 present and former staff members of misfeasance in public office and sought damages of $£ 1$ billion.

38 BBC News, Bank awarded £73m in BCCl costs, 7 June 2006

(http://news.bbc.co.uk/1/hi/business/5056056.stm; accessed 4 January 2012)

${ }^{39}$ Hansard, House of Common Debates, 27 February 2007, col. 1300.
} 
proceedings where that person is not party to the legal proceedings. If you propose to seek a copy of the Report from the Court, you may find it helpful in making your application to cite the following legal proceedings: Bank of Credit and Commerce International (Overseas) Ltd (in liquidation) and others $v$ Price Waterhouse and others and Three Rivers District Council \& others $v$ The Governor and Company of the Bank of England"

The above seemed to suggest that Treasury was content for Sikka to obtain a copy of the Sandstorm Report, as long as it was not seen to be releasing it (see more below). Thirdly, the 28 March 2007 letter said that

"The demise of $\mathrm{BCCl}$ remains a sensitive issue and we have needed to consult others over the release of the information in this report. We have also had to consider the legal position in relation to the release of the individual pieces of information in the report that are not readily available to the public and consider whether release would be prohibited by section 44 of the Freedom of Information Act. ... we are able to release to you some additional unpublished information from the draft report ....".

The "additional unpublished information" released by the Treasury was Section 1 of the Sandstorm Report and headed 'History and current status of problems'. It consisted of four pages of text and was not really new as it was freely available from the US Congress Library. It is just that some of these pages were not placed by Sikka on the internet. Fourthly, the Treasury was unwilling to release the missing parts of the version of the Report available from the US Congress Library and the internet. Its position was that

"The information constitutes personal data, and disclosure would in our view contravene data protection principles. Section 40(2) is an absolute exemption and we are not required to consider the public interest in release. ... In this instance we consider in particular that the release of names would breach the First Data Protection Principle. Where names have not been mentioned in evidence during litigation and are not otherwise in the public domain we consider that it would not be fair to release the names, even after 16 years. ... In relation to the release of names where the fact and nature of individuals' connections with $\mathrm{BCCl}$ may have already been made public by others not subject to the Data Protection Act, we consider that does not absolve us from our duty to consider the conditions on disclosure related to it ...".

Fifthly, the Treasury invoked disclosure exemptions under the FOIA and said that it would not release the key names on the basis that

"...the release, by the UK government, of this information would be likely to provoke a negative reaction that would damage the UK's international relations and may harm its ability to protect and promote UK interests abroad" 
To sum up, the Treasury did not provide any of the missing information. It justified its refusal by using the public interest exemptions contained in the FOIA. However, it also indicated that a copy of the report could be obtained from the courts though it did not identify the court(s) or the process by which someone can obtain a document filed with it.

On 14 June 2007, Sikka wrote to Her Majesty's Court Service (HMCS) and requested a copy of the Sandstorm Report. The HMCS replied (24 July 2007) stating that it could identify six cases relating to $\mathrm{BCCl}$ during the period 1997 to 2005. Three files had been destroyed because the documents were over five years old and no trace of the Sandstorm Report could be found in the other three files. This information was passed to the Treasury on 31 July 2007 and the Department was asked to review its previous decision to withhold the Sandstorm Report. A reminder (14 September 2007) failed to elicit any further response. Following a prolonged period of silence, the matter was again raised in the House of Commons on 7th January 2008 and the Chancellor said that the "Treasury is currently considering this case in response to an internal review request made by Professor Sikka in September 2007 under the Freedom of Information Act. A decision will be reached shortly ${ }^{40 "}$.

On 13th March 2008, the Treasury finally communicated the result of its internal review. It refused to provide the withheld information and cited the Data Protection Act 1998 and the Human Rights Act 1998 to argue that release of the information would violate privacy of the

"individuals who were employed, or had been employed by $\mathrm{BCCl}$; also the names of individuals who had had financial dealings with $\mathrm{BCCl}$... It is not easy to ascertain who was tried and found guilty of offences in relation to $\mathrm{BCCl}$, but where individuals were tried and found guilty of offences they would have received appropriate punishment from the courts and it would be unfair, after this time, to publicise their involvement again. For those employed by $\mathrm{BCCl}$ who had not been found guilty of any offence it would be unfair to release information about their association with $\mathrm{BCCl}$ as this might be detrimental to them in their current employment or their employment prospects. The same reasoning applies to those who had financial dealings with $\mathrm{BCCl} . . . "$

In addition, the Treasury repeated its previous assertion that the public interest in releasing the information was outweighed by the

${ }^{40}$ Hansard, House of Common Debates, 7 January 2008, col. 340. 
"public interest in maintaining good relations with other states. ...the sensitivity here is not so much around new information finding its way into the public domain, but in relation to the damage likely to be caused through the release by the UK government (emphasised in the original) of this information".

The above was considered to be unsatisfactory. For example, if the wrongdoers have already been identified and punished, it is difficult to see how their human rights were being protected by withholding the contents of the Sandstorm Report. The identity of these individuals would probably already be known to employers in the finance industry and in any case they would be obliged to provide a truthful account of their employment history on their job application forms. Some may also have died in the intervening years. If any employees, depositors or lenders were innocently caught up with BCCI frauds, the Treasury could redact their names and release the rest.

\subsubsection{The Information Commissioner}

On 16 May 2008, the Information Commissioner was invited to adjudicate the dispute. The Information Commissioner acknowledged the request on 12 June 2008 and an email on 12 December 2008 said that the matter "is awaiting assignment to a case officer. We will contact you again with further updates". Another email, dated 15 June 2009, stated that the matter has now been assigned to a case officer and a decision would be made in due course.

On 3rd July $2009^{41}$, nearly fourteen months after the initial complaint, the Commissioner finally wrote to the Treasury and asked to see a full copy of the Sandstorm Report along with detailed submission of the Treasury's case for withholding information ${ }^{42}$. Further exchanges took place on 5 August and 21 September 2009. In an email, on 21 September, the Information Commissioner's office informed Sikka that some progress was being made on his case. Finally on 14th December 2009, the Commissioner issued a Decision Notice ${ }^{43}$. The 21 page document written in dense legal language criticised the Treasury for breaches of the rules for processing requests and unreasonable delay in reaching its conclusions

\footnotetext{
${ }^{41}$ Paragraphs 21-23 of the Decision Notice issued by the Information Commissioner on 14th December 2009 (see http://www.ico.gov.uk/upload/documents/decisionnotices/2009/fs_50202116.pdf).

42 Sikka was not shown any of this correspondence and was therefore not in a position to comment on the contents.

${ }^{43}$ Case Number FS50202116, available at http://www.ico.gov.uk/upload/documents/decisionnotices/2009/fs_50202116.pdf.
} 
(paragraphs 88, 90-93). However, it stated (paragraph 87) that "The Treasury was correct to withhold the parts of the report that it did not disclose to the complainant on the basis of the exemptions contained in section 21, 40(2) and 27(1)(a) of the Act".

\subsubsection{The Appeal}

Paragraph 94 of the Decision Notice reminded the parties that they can appeal against the Commissioner's decision by filing a Notice of Appeal within 28 calendar days. The Decision Notice was not accompanied by a form which would need to be completed to lodge an appeal with the Information Tribunal though it contained a website address for further information.

Unlike most of the previous correspondence, the Decision Notice was not sent electronically to Sikka. Instead, it was mailed by the Commissioner's office on 14 December 2009, during the last week of the academic term, to his university address. Royal Mail confirmed that the document was delivered the next day to Sikka's work address, but he did not see it. The next few days coincided with attendance at conferences, followed by the closure of the university for the Christmas and New Year break. Sikka was not alerted to the imminent arrival of the Decision Notice and thus could not make alternative arrangements to open or redirect his mail. Heavy snow falls in early January, chaotic transport and various research commitments meant that Sikka first saw the Decision Notice on 18 January 2010, well after the 28 day appeal period which expired on 12 January 2010. In common with most laypersons Sikka only had a rudimentary knowledge of the freedom of information law and therefore sought pro bono advice from a number of specialist law firms as well as the pro bono unit at the Bar Council. Some law firms promised to contact him within the next few days though in the event none offered pro bono assistance. He was now even further away from the 28 day deadline and the only option appeared to be to represent himself in person in the courts. As part of the preparation for the Appeal Sikka tried to establish from the Information Commissioner (email 11 February 2010) whether the availability of the Sandstorm Report to a number of parties (courts, US Senate Committees, newspapers, Sheikh of Abu Dhabi) constituted a "publication", but this line of inquiry was not productive. A study of the tribunal procedures (Jacobs, 2009) suggested that late appeals were possible as the judges had some discretion. An email, 24 February 2010, from the Commissioner's Office confirmed that late appeals may be permitted at the Tribunal's 
"discretion". On the same day guidance was sought from the Information Tribunal and the reply was that the "decision as to whether an out of time appeal is accepted rests with the Principal Judge. ...You will need to put in detail the reasons why the appeal is out of time and why you think the Tribunal should accept it". This advice was followed and an appeal was lodged with the First-Tier Tribunal (FTT) on 2 March 2010, some 46 days after the expiry of the 28 day notice period. Sikka had little knowledge of case law and thus did not cite any legal precedents and besides this was not considered to be a good strategy in combating the legal expertise available to the Information Commissioner. So the Appeal Form primarily stated the reasons (as cited above) for the delay. The appellant sought a paper rather than an oral hearing as this was economical and less disruptive ${ }^{44}$. In any case, a face-to-face engagement with the lawyers representing the Information Commissioner was not considered to be advantageous.

The FTT invited the Information Commissioner to comment on the late appeal, and he opposed (email dated 26 March 2010) it by arguing that "there is no good reason to allow this appeal out of time. The Tribunal should not therefore exercise its discretion under rule 5(3)(a) of the 2009 Rules to extend time ...". The Tribunal wrote to Sikka, on 29 March 2010, and said that "In view of what they [Information Commissioner's Office] say the Tribunal is inclined to reject the appeal. However, before doing so the Tribunal would like to give you a further opportunity to explain why your appeal should be accepted ...". Sikka responded on 31 March 2010, emphasising the importance of the missing information and the case, and the fact that a number of parties had already seen the unredacted version of the Sandstorm Report. On 9th April 2010, Judge John Angel permitted Sikka's late appeal to proceed by stating $^{45}$ that

"I have taken all these matters into account ... I have decided that in all the circumstances of this particular case it would be just and fair to allow this appeal to proceed (paragraph 13 of the judgement ${ }^{46}$ )".

${ }^{44}$ For example, Sikka would not need to reschedule classes to make court appearances.

45 Professor Prem Sikka v Information Commissioner (The Tribunal Procedure (First-tier Tribunal) (General Regulatory Chamber) Rules 2009) [2010] UKFTT EA_2010_0054 (GRC); available at

http://www.justice.gov.uk/downloads/tribunals/information-rights/how-to-appeal/Prof-Sikkavs-IC-Ruling-0410-9.4.10_w.pdf

46 The judgment established new principles for allowing late appeals and stated that amongst other things the Tribunals should consider the reasons for the delay, complexity of the decision being appealed, the fact that the appellant is unrepresented and unfamiliar 
The judgment seemingly cleared the path for the substantive case, i.e. the release of the missing parts of the Sandstorm Report, to be heard. However, possibly fearing a flood of late appeals, on 7 May 2010, the Commissioner made an application to FTT for 'Permission to Appeal' against the judgment which permitted Sikka's late appeal to proceed ${ }^{47}$. Judge John Angel reviewed his decision on 17th May 2010 and concluded that no error in law had been established and the permission to appeal was refused ${ }^{48}$. The Judge informed the Commissioner (email dated 17 May 2010) that he can "apply directly to the Upper Tribunal for permission to appeal ...". Meanwhile, the judge ordered that the parties prepare for the substantive hearing. The Treasury Department, the recipient of the original request to release the Sandstorm Report, was joined as an additional party to the dispute and the parties (Sikka, Information Commissioner and a lawyer for the Treasury) proceeded to draw up a timetable for exchanging documents and witness statements, etc. Judge Christopher Ryan was appointed to hear the case and on 6 July 2010 issued Directions, ordering the parties to submit arguments for/against the release of the missing parts of the Sandstorm Report.

In accordance with Judge Ryan's Directions Sikka began preparation of his detailed case and collected witness statements ${ }^{49}$. However, the proceedings were to be delayed as on 14 July 2010 the Information Commissioner did two things. Firstly, he asked the Upper Tribunal with an application for permission to appeal against the FTT judgment, which allowed Sikka's late appeal. Secondly, he also sought a judicial review of the FTT

with the appeal process and the public interest in the disputed information. Following the judgement, it is possible to apply for an extension of time to appeal before lodging the actual appeal. Since May 2010, the instructions issued by the UK Department of Justice for completion of the Notice of Appeal form for freedom of information disputes refer appellants to the "Ruling in Prof Sikka v Information Commissioner dated 9 April 2010".

${ }^{47}$ Sikka was invited to add his observations on the appeal.

${ }^{48}$ See the final four pages of http://www.justice.gov.uk/downloads/guidance/courts-andtribunals/tribunals/information-rights/how-to-appeal/Prof-Sikka-vs-IC-Ruling-0410-

9.4.10_(w).pdf

${ }^{49}$ These included a statement from Washington DC lawyer Jack Blum, an adviser to the US Senate Committee which investigated the $\mathrm{BCCl}$ frauds (United States Senate Committee on Foreign Relations, 1992). Blum is credited with first uncovering BCCl frauds. Witness statements were also provided by a number of NGOs and journalists, legislators, a former member of the UK House of Commons Treasury Committee, a former US partner of PricewaterhouseCoopers and two UK accounting academics, Professor Michael Jones and Professor Jill Solomon. 
decision ${ }^{50}$. The two routes were being pursued because there was some uncertainty about how best to challenge the FTT judgment, especially as the FOIA was relatively new and there were few, if any, cases of late appeals. In view of the appeal, the Upper Tribunal judge ordered a stay on the proceedings and the parties awaited the next steps. On 6 September 2010, Sikka was informed that "the Information Commissioner's applications will now proceed to be heard at an oral hearing before the Upper Tribunal. The object of the hearing will be to assist the Upper Tribunal in its consideration of the Information Commissioner's arguments in relation to the First-tier Tribunal's decision to admit your late appeal". The oral hearing was set for 2 December 2010 in London and Sikka was ordered to appear in person.

On a bitterly cold snow-covered morning, at a hearing in London, the Information Commissioner was represented by the head of the legal department and Timothy PittPayne QC, described on his firm's website ${ }^{51}$ as a "very persuasive advocate ... intellectual power second to none ... leading advocate in Freedom of Information Law". Sikka appeared in person and did not have any legal advisers ${ }^{52}$. Timothy Pitt-Payne QC spoke for about seventy minutes and made an eloquent case for overturning the decision to allow Sikka's late appeal. Due to lack of legal know-how Sikka could not engage in legal banter and only spoke for about 10-15 minutes to mainly defend the previously given reasons for the late appeal. He also argued that if in the absence of any significant errors in law the Upper Tribunal overturned the discretion exercised by a lower court (the First-Tier Tribunal) judge, then that would undermine and effectively destroy the court system. Towards the end of the hearing, the Upper Tribunal judge Nicholas Wikeley gave both parties a copy of the recent judgment in CD v First Tier Tribunal (CICA) [2010] UKUT 181 (AAC) (01 June 2010) and invited them to consider whether in the light of this case they wished to make a further written submission. In effect, the judge had asked the parties to interpret the case and possibly voluntarily reconsider their position. The $C D$ case, not relating to freedom of information, was interesting in that the appellant was nine months out of time and had given inadequate reasons for at least 4 months of that delay, and had a case which appeared

\footnotetext{
${ }^{50}$ Information Commissioner v First Tier Tribunal Information Rights: Interested Party Professor Prem Sikka - Judicial Review Application J R/1600/2010

51 http://www.11kbw.com/barristers/detail.php?bid=21; accessed on 30 January 2012.

52 There were five people in attendance: Judge Nicholas Wikeley, the court clerk, the Head of legal services at the Information Commissioner's Office, Timothy Pitt-Payne QC and Prem Sikka.
} 
likely to struggle. The FTT judge had rejected the late appeal and that decision was upheld by the Upper Tribunal. More importantly, the Upper Tribunal judgement did not overturn the discretion exercised by the FTT judge. Sikka made his written submission on 10 December 2010. On 19 January 2011 the Upper Tribunal issued further directions and invited the parties to consider the significance of $L S v$ London Borough of Lambeth (HB) [2010] UKUT 461 (AAC). The Commissioner's legal representatives responded on 17 February 2011, whilst due to lack of legal knowledge Sikka mainly rehearsed his previous position. He also urged the judge to compare his 46 days delay to the time taken by the Treasury and the Commissioner in responding to his requests. On 7 March 2011, Judge Nicholas Wikeley issued a 17 page judgement ${ }^{53}$ and stated (paragraph 2) that

"... my decision is to give the Information Commissioner permission both to appeal and to apply for judicial review, on the basis that the grounds are arguable, but to dismiss the substantive appeal and the application for judicial review. In short, I have concluded there was no material error of law in the First-tier Tribunal's decision. As a result, Professor Sikka's substantive appeal to the First-tier Tribunal against the Information Commissioner's Decision Notice should now proceed"

Thus, some five years after the initial request, the ground was cleared to hear the arguments for/against the release of the missing parts of the Sandstorm Report.

\subsubsection{The Substantive Case and the Outcome}

The case now returned to Judge Chris Ryan and on 8 March 2011, he directed that the previously stalled process (stalled in July 2010) will now proceed. The time table was that by 21 March 2011, the parties would provide copies of background information (e.g. letters providing history of the case). This was also the deadline for the Treasury to provide the Tribunal with a copy of Sandstorm Report. By 27th April, the parties had to exchange with each other and serve on the Tribunal any written witness statements and by 11 May 2011, the parties had to exchange their written submissions and lodge with the Tribunal together with any authorities and statutory materials.

${ }^{53}$ Upper Tribunal (Administrative Appeals Chamber), March 07, 2011, [2011] UKUT 94 (AAC) Information Commissioner v PS [2011] UKUT 94 (AAC), and GIA/1488/2010 and $\mathrm{JR} / 1600 / 2010$ Information Commissioner v PS [2011] UKUT 94 (AAC);Available at http://www.osscsc.gov.uk/judgmentfiles/j3215/GIA\%201488\%202010-00.doc 
The lawyers representing the Treasury, however, secured a vital concession from the judge in that it did not have to show its arguments and evidence for opposing the release of information to Sikka. The evidence would only be available to the Tribunal and its members could then decide whether in the light of arguments advanced by Sikka the disputed information could be released. The logic was that the Sandstorm Report was confidential and so were the arguments was the case, including witness statements, for withholding its release. Indeed, most of the evidence subsequently submitted by the Treasury, which included a full witness statement from a senior Foreign Office official, on 9 May 2011, was considered to be confidential and Sikka was unable to cross-examine it. The same logic did not apply in reverse. The restrictions meant that the responsibility for cross-examination fell on the Tribunal members. Therefore, it became vitally important to provide some ammunition to the Tribunal to enable it to interrogate the Treasury's case.

On 22 April 2011, Sikka filed a 41 page affidavit ${ }^{54}$, accompanied by 19 witness statements, to advance arguments for the release of the missing information. Sikka had by now some awareness of the case law and possible interpretations of legislation (for example, see Carter and Bouris, 2006), but chose not to make them the central pieces of his arguments. In the absence of legal advisers, he was not sure whether these interpretations were appropriate and more importantly such a move would have enabled the Treasury's and the Commissioner's lawyers to excel by providing authoritative counter interpretations. Obviously, the judges knew that it was a contest between a layperson and lawyers funded by the state and as a result may well have been sympathetic to the layperson. So the concern was to provide judges with arguments with which they could interrogate the Treasury's case for withholding information. The affidavit provided background to the $\mathrm{BCCl}$ frauds, the significance of the Sandstorm Report, silence of the UK government, the public availability of large parts of the Sandstorm report and emphasised the age of the information, which by now was nearly twenty-years old, together with a variety of arguments that the public interest would be served by the release of the Sandstorm Report. By March 2011, the US Congress Library had digitised some of its archives and as a result a large volume of $\mathrm{BCCl}$ related information became publicly available ${ }^{55}$. The affidavit wondered

\footnotetext{
${ }^{54}$ Available at http://visar.csustan.edu/aaba/BCCl\%20Final\%20Statement\%20Sikka\%20\%2022\%20April\%202011.pdf

${ }^{55}$ For example, see http://catalog.hathitrust.org/Record/007608474; for further links see http://visar.csustan.edu/aaba/bccipage.html.
} 
what if further digitisation resulted in the publication of a complete copy of the Sandstorm Report. Subsequent, emails suggested that the Treasury was not aware of the public availability of this information. After the BCCl scandal, the Bank of England was stripped of its regulatory role, but in July 2010 the incoming Conservative administration decided to restore its former regulatory role ${ }^{56}$. In view of the change, its previous conduct was thought to be of public significance and was mentioned in the affidavit.

On 5 May 2011, the Tribunal asked the parties for three additional items of information. These were, 1) a copy of the internet version of the Sandstorm Report. It would be recalled that this was placed on the internet by Sikka; 2) a full copy of the Bingham Report (Bingham, 1992), presumably to establish whether it contained any of the disputed information (see above); and 3) a hard copy of the US Senate report on BCCI (United States Senate Committee on Foreign Relations, 1992) from which Sikka had liberally quoted in his affidavit. There is an internet version of the US Senate report ${ }^{57}$; but its contents are not identical to the hard copy. Sikka provided a copy of the first item and in the event the Treasury provided extracts from the previously published Bingham Report, to support the arguments that the information sought by Sikka was mostly already publicly available and that the release of the withheld information would not be a significant addition. However, the Treasury did not have a hard copy of the US Senate Report. On 9 May 2011, the Treasury cross-examined Sikka' affidavit and filed a contrary statement and Sikka filed a rebuttal on 11 May 2011. The Information Commissioner also filed a contrary statement on 11 May 2011 and argued that the Tribunal should view the public interest in the withheld information from the perspective of 6 March 2006 (the date of the original request for information) rather than at the date of hearing. This was supported by case law and was intended to negate Sikka's arguments that the return of the Bank of England as a banking regulator had made the release of the Sandstorm Report of greater public significance. Sikka filed a rebuttal on 11th May.

\footnotetext{
${ }^{56}$ UK Treasury press release 26 July 2010 (http://www.hmtreasury.gov.uk/press_32_10.htm).

${ }^{57}$ Available at http://www.fas.org/irp/congress/1992_rpt/bcci/.
} 
On 11 July 2011, in a 17 page verdict, covering 52 paragraphs, in the case of Professor Prem Sikka v Information Commissioner, EA/2010/0054, 11 July 2011 $1^{58}$, Judge Chris Ryan, and two other members of the Tribunal, unanimously said that

"The Treasury is therefore directed to disclose to Professor Sikka, within 35 days of the date of this decision, an unredacted form of the Sandstorm Report and its covering letter, save only for the names set out in Confidential Schedule ${ }^{59}$, which may be redacted" (paragraph 50).

"In our view there is considerable public interest in the public seeing the whole of the Sandstorm Report so that it can be seen, not just what happened, but what role was played by the governments, institutions and individuals who were involved with an organisation guilty of what the authors of the Sandstorm Report (paragraph 10.1) described as "an enormous and complex web of fictitious transactions in what is probably one of the most complex deceptions in banking history"' (paragraph 29).

In response to the concerns that the disclosure would somehow prejudice relationship with one or more other states, the Tribunal said that

"The public has an interest in seeing how each of those who carried out an investigation illuminated the facts and assessed the actions of those who were involved, whether they contributed to the problems, tried to resolve them or played a neutral role. The weight we apply to this element of public interest has been heavily influenced by our view of the importance of the events surrounding the collapse of $\mathrm{BCCl}$, the serious ramifications it had for many innocent people caught up in it and the questions it raised about the regulation and auditing of a large international institution" (paragraph 30).

The Treasury and the Information Commissioner were rebuked for their interpretation of the data protection and privacy laws to shield individuals who were "the architects of a groupwide programme of fraud and concealment, not to mention the creation of a culture that led others with positions of responsibility within the bank to follow their lead" (paragraph 42). The Tribunal made a distinction about the seniority of the individuals and how they performed at the time and on that basis ordered that the names of

“... those having senior management positions in either $\mathrm{BCCl}$ or other organisations that were closely involved in the unlawful elements of its activities should be identified" (paragraph 36c).

\footnotetext{
${ }^{58}$ Available at http://www.informationtribunal.gov.uk/DBFiles/Decision/i544/20110909\%20Decision\%20an d\%20Conf\%20Sch\%202.pdf

${ }^{59}$ The nature of this Schedule is explained in the judgement.
} 
The Tribunal also ordered the release of he names of most of the customers, on the basis that they

"were not ordinary customers, but had become involved in the many complex and frequently incestuous transactions that enabled the $\mathrm{BCCl}$ management and a number of organisations and individuals close to it to commit or conceal fraud. Those frauds led to severe financial hardship for many of the "ordinary" customers and we have explained in Confidential Schedule $2^{60}$, by reference to each individual, why we consider that there is a legitimate interest in disclosing their involvement and that this will not cause unfairness or unwarranted intrusion into their privacy"

The judgement set a new legal precedent, making it difficult for the government to withhold the names of the wrongdoers. The Treasury was given 35 days to comply with the court order. It was also given the right of appeal. Subsequently, at Treasury's request (4th August 2011) the period was extended by another 28 days because "the decision in the appeal at issue related to a highly sensitive report ... the process is taking some time due to the need to consult widely within the Foreign and Commonwealth Office ...". On 7 September 2011, the Treasury informed the Tribunal it will not appeal the decision and on the same day, nearly five and years after the initial request, most of the Sandstorm Report was released to Sikka.

By comparing the version held in the US Congress Library (and also on the internet) with the version released by the UK Treasury, the information concealed by the UK government could now be read ${ }^{61}$. It mainly related to the names of individuals and organisations. The individuals included Sheikh Sultan bin Zayed, ruler of Abu Dhabi; various members of the royal family of Abu Dhabi; Prince Turki, a member of the Saudi royal family; Sheikh Kamal Adham, thought to be the one-time head of Saudi intelligence services; Sheikh Sharqi, the Emir of Emir of Fujaira; Pharon, a Saudi businessman and financier and Clark Clifford, a former US Defence Secretary and Presidential adviser. The UK government shielded the identity of some individuals who had died in the intervening years. These included $\mathrm{BCCl}$

\footnotetext{
${ }^{60}$ Available at http://visar.csustan.edu/aaba/BCCl\%20Sandstorm\%20Confidential\%20Schedule.pdf. It is also part of the Tribunal judgement available at http://www.informationtribunal.gov.uk/DBFiles/Decision/i544/20110909\%20Decision\%20an d\%20Conf\%20Sch\%202.pdf.

61 The comparison is available at http://visar.csustan.edu/aaba/BCCISandstormRelease.html.
} 
founder Agha Hassan Abedi (died in 1995 ${ }^{62}$ ) and Saudi billionaire Sheikh Khalid bin Mahfouz (died 2009) who in 1993 paid $\$ 225$ million to settle US charges of bank fraud ${ }^{63}$ in 1993. A number of $\mathrm{BCCl}$ executives had been convicted of fraud, but their identity was still being withheld by the UK government. These included Mohammed Swaleh Naqvi, Ziauddin Akbar ${ }^{64}$. Perhaps, to defend the reputation of some jurisdictions, the UK government also concealed the names of some places. Examples include Grand Cayman, Bahrain, the name of a Turks and Caicos company, North American Finance and Investment, Arab Livestock Company (ALSCO) operating from Bahrain, Saudi National Commerce Bank operating from Bahrain and Royal Bank of Scotland, Singapore. The names of a number of corporations, including Bear Stearns, Abu Dhabi Investment Authority, Capcom, Credit Suisse, Dubai Islamic Bank, Gokal Brothers, Habib Bank and National Bank of Georgia were also concealed.

One of the issues throughout the final Tribunal hearing was that the Treasury's evidence/arguments about withholding the information were "closed". Following the Tribunal's judgement, Sikka informally inquired (email dated 29 July 2011) whether the judge would now declare the evidence "open", thus enabling the public to see how the Treasury interpreted, constructed and defended secrecy. In reply, the judge stated (email dated 2 August 2011) that "the particular nature of the evidence in ... this case means that this is one of the occasions when it must still remain confidential". In principle, a formal legal process could have been launched to secure the evidence but was not pursued.

\subsection{Summary and Discussion}

Accountability and openness may be promoted as the cornerstones of democracy and responsible governance, but there is a difference between ideals and practices, promises and their implementations. This paper has provided as objective an account as is possible of two encounters with the UK state apparatus to show that despite the promises, the provision of information is frustrated and obstructed by bureaucratic and legalistic

\footnotetext{
62 New York Times, 6 August 1995 (http://www.nytimes.com/1995/08/06/obituaries/aghahasan-abedi-74-dies-in-the-shadow-of-a-vast-fraud.html )

63 New York Times, 26 August 2009 (http://www.nytimes.com/2009/08/27/world/middleeast/27mahfouz.html).

64 The Independent, 15 June 1994 (http://www.independent.co.uk/news/business/bcci-menjailed-and-ordered-to-pay-dollars-9bn-by-abu-dhabi-court-former-chief-executive-andfounder-of-collapsed-bank-sentenced-in-their-absence-1422790.html).
} 
processes. It supplements previous research showing that the UK state's impulse is often to shield selected elites (Mitchell, Sikka and Willmott, 1998), and elites themselves are also adept at using resources to obstruct calls for explanations of their conduct (Mitchell and Sikka, 2004).

The two case studies presented in the paper are based upon data generated by freedom of information requests, which arguably had the potential to increase understanding of banking frauds, auditing and regulation. Both cases related to well known banking scandals and engaged with key state officials, including various ministers, civil servants, Information Commissioner and judges. In principle, the freedom of information law can enable citizens to construct a richer account of corporate scandals and frauds, and call policymakers to account, but the paper drew attention to numerous difficulties in securing the information. The government departments are not obliged to list the documents that they hold, which an interested citizen can then request. Rather the citizen somehow needs to be aware that a document may exist before requesting it. Concerned citizens have to negotiate laws which invoke notions of the 'public interest' to withhold information. Challenging official bureaucracy is difficult because laypersons are unlikely to have familiarity with case law or the complexities of legal language used, but public authorities have considerable legal resources.

In the case of Ramor Investments, only a persistent engagement with the state officials resulted in the release of some snippets of information. Without any public announcement, the government officials acted as judge, juries and arbiters of the pubic interest and destroyed key documents. The destruction of key documents continued even after the request for information was made and before the liquidation of the bank was finalised. The DBIS claim that it did not hold the final unpublished report on the collapse of Ramor Investments cannot be independently corroborated and the Information Commissioner seems to have been persuaded to accept the Department's line. There were long delays in processing requests and other than an admonishment from the Commissioner there appeared to be no consequences for the DBIS. The Department was not fined, gave no undertakings for its conduct in the future, or explained how its procedures and processes would be improved. The information released by the DBIS showed that the state officials went to considerable lengths to shield Price Waterhouse and others from public scrutiny. In the face of fraud, government departments entered into private and confidential agreements 
with some elites to protect their identity. The inspectors investigating the Ramor collapse expressed some unhappiness with the non-publication of their report, but these were overridden in the anxieties to protect elites from public scrutiny. Seemingly, the subjectivity of the state officials is constructed in such a way that they have internalised the need to shield accountancy firms and elites from scrutiny.

In the case of $\mathrm{BCCl}$, Sikka muddled through the legalistic processes and even the judges found some of his arguments to be "limited" and "inconclusive", but eventually a successful outcome was secured. The Information Commissioner promotes himself as "the authoritative arbiter of information rights, delivering high-quality, relevant and timely outcomes, responsive and outward-looking ... ${ }^{65}$ ", but took a long time to respond and even then supported the Treasury's refusal to release the Sandstorm Report. The eventual release of the most of the Sandstorm Report showed that the state was shielding some individuals who had already been convicted of fraud, or had direct involvement in frauds, including those who died in the intervening years. It was shielding well known individuals from the Middle East, and attached little weight to the UK citizens' right to know. The involvement of Middle East elites in $\mathrm{BCCl}$ frauds did not prompt the UK government to withdraw ambassadors, close their embassies, or make public demands for restitution. It simply covered up their identities, possibly to promote and defend the interests of corporations exporting arms to the Middle East, or the interests of elites in a politically sensitive part of the world. Even today the Sandstorm Report cannot be found on the UK Treasury's website. Under the FOIA, the public authorities are only obliged to release the information to the party requesting it. Therefore, the UK Treasury's obligation was discharged by releasing the information to Sikka, rather than to the public at large.

The contents of the Sandstorm Report also pose questions about the Bank of England's regulatory role. In the late 1990s, after the $\mathrm{BCCl}$ debacle, it lost its regulatory role, but in 2011 it was restored to its former regulatory role by the incoming Conservative and Liberal Democratic coalition administration. Given that it went to considerable lengths to shield wrongdoers, the likelihood of it being open and honest with parliament and the general public must be doubted. Citizens may seek a fuller account of banking frauds to call

${ }^{65}$ Page 6 of the Information Commissioner's Annual Report 2009/10 (http://www.ico.gov.uk/upload/documents/library/corporate/detailed_specialist_guides/annu al_report_2010.pdf) 
regulators and governments to account, but the Sandstorm Report provides only a tiny glimpse of the $\mathrm{BCCl}$ affair. A reading of various documents suggests that there are other unpublished coded reports, such as "Fork" and "Tumbleweed" and may be many more. As it has taken nearly five and half years to secure one document, the possibility to speedily securing other documents and constructing a fuller picture must be doubted. Much of the accounting and regulatory history is constructed from official narratives because the contemporary standards of objectivity ascribe a certain kind of hardness to official reports. However, there is a possibility that the selective release or withholding of information only succeeds in constructing a certain kind of history, which lets elites off the hook.

Arguably, it is difficult to reach generalised conclusions from two case studies, but they draw attention to gaps between the public promises of accountability and bureaucratic practices that thwart the provision of information. It may be argued that the Information Commissioner and the Information Tribunals played a key role in securing release of some of the information about Ramor and $\mathrm{BCCl}$ and that this shows that the state is responsive. This assumes that it is reasonable for citizens to toil for years to obtain snippets of information. The freedom of information laws may enable citizens to secure some pieces of useful information, but cannot reconcile the tensions between secrecy, democracy, privacy and the pursuit of private and public interests because they are inherent in neoliberalism. The extent of tensions is likely to depend on local histories and institutional structures. Hopefully, others would engage with the state apparatus to provide further insights into the politics

of

accountability. 


\section{References}

Ahrens, T. Styles of accountability. Accounting, Organizations and Society, 1996: 21(2/3):139-73.

Arnold, P. and Sikka, P. Globalization and the State-Profession Relationship: The case of the Bank of Credit and Commerce International, Accounting, Organizations and Society, 2001: 26(6): 475-499.

Barone, S. D. Secrecy in the Bush Administration, New York: Nova: 2006.

Beck, U. Risk society: Towards a new modernity, London: Sage: 2003.

Bennett, C. From the Dark to the Light: The Open Government Debate in Britain, Journal of Public Policy, 1985: 5(2): 187-213.

Bingham, The Right Honourable Lord Justice. Inquiry into the Supervision of The Bank of Credit and Commerce International, London: HMSO: 1992.

Birkinshaw, P. Freedom of information and its impact in the United Kingdom, Government Information Quarterly, 2010: 27(4): 312-321.

Board of Banking Supervision, Report of the Board of Banking Supervision inquiry into the circumstances of the collapse of Barings, London: HMSO: 1995.

Broadbent, J. and R. Laughlin (2003), Control and legitimation in government accountability processes: the private finance initiative in the UK, Critical Perspectives on Accounting, 2003: 14(1-2): 23-48.

Brooke, H. The Silent State: Secrets, Surveillance and the Myth of British Democracy, London: Heinemann: 2010.

Carter, M. and Bouris, A. Freedom of Information: Balancing the Public Interest, London: The Constitutional Unit, School of Public Policy, University of London: 2006 (http://www.ucl.ac.uk/spp/publications/unit-publications/134.pdf).

Castells, M. The rise of the network society, Chichester: Wiley: 2010.

Cousins, J., Mitchell, A. and Sikka, P. Secret Government and Privileged Interests, Political Quarterly, 1993: 64(3): 306-314

Ellington, T.C. Secrecy and disclosure: Policies and consequences in the American experience, in Susan Maret (ed.) Government Secrecy, Bingley: Emerald: 2011: 67-90.

Foucault, M. The Eye of Power, in C. Gordon (ed.) Power/Knowledge: Selected Interviews and Other Writings 1972-1977. New York: Pantheon Books: 1980

Habermas, J. Legitimation Crisis, Heinemann, London: 1976 
Hall, P.A. and Soskice, D. An Introduction to Varieties of Capitalism' in Hall, P.A. and Soskice, D. (eds.), Varieties of Capitalism: The Institutional Foundations of Comparative Advantage. Oxford: Oxford University Press, pp.1-70, 2001.

Hennessy, P. The Secret State: Preparing for the worst 1945-2010, London: Penguin: 2010.

Hirst, P.Q. Associative democracy: New forms of economic and social governance, Cambridge: Polity: 1994.

Hood, C. and Heald, D. Transparency, The Key to Better Governance? Oxford: Oxford University Press: 2006.

Information Commissioner's Office, Freedom of Information Act Awareness Guidance No 3: The Public Interest Test, 2006 (http://www.ico.gov.uk/upload/documents/library/freedom_of_information/detailed_specialist _guides/awareness_guidance_3_-_public_interest_test.pdf).

Jacobs, E. Tribunal Practice and Procedure - Tribunals under the Tribunals, Courts and Enforcement Act 2007, London: Legal Action Group: 2009.

Killick, M. Fraudbusters: The Inside Story of the Serious Fraud Office, London: Indigo: 1998.

Laclau, E. and Mouffe, C. Hegemony and Socialist Strategy, New York: Knopf Doubleday: 1985.

McSweeney, B. Action Research: mission impossible? Commentary on "Towards the increased use of action research in accounting information systems", Accounting Forum, 2000: 24(4): 379-390.

Mitchell, A. and Sikka, P. Accountability of the Accountancy Bodies: The Peculiarities of a British Accountancy Body, British Accounting Review, 2004: 36(4): 395-414.

Mitchell, A., Sikka, P., Cooper, C., Arnold, P. and Willmott, H., The BCCI Cover-Up, Basildon: Association for Accountancy \& Business Affairs, 2001.

Mitchell, A. Sikka, P. and Willmott, H. Sweeping it under the carpet: the role of accountancy firms in moneylaundering, Accounting, Organizations and Society, 1998: 23(5/6): 589-607.

O'Connor, J. The Meaning of Crisis: A Theoretical Introduction, Basil Oxford: Blackwell: 1987

O'Neill, O. BBC Reith Lectures: Trust and Transparency. 2002 (http://www.bbc.co.uk/radio4/reith2002/lecture4.shtml).

Offe, C. Contradictions of the Welfare State, London: Hutchinson: 1984.

Palast, G., The Best Democracy Money Can Buy, London: Pluto: 2002. 
Pierson, P. Dismantling the Welfare State? Reagan, Thatcher and the Politics of Retrenchment, Cambridge: Cambridge University Press: 1994.

Pilger, J. Hidden Agenda, London: Vantage: 1998.

Ponting, C., The right to know: The inside story of the Belgrano affair, London: Sphere Books: 1985.

Ponting, C., Secrecy in Britain, Oxford: Blackwell: 1990

Reid, M., The Secondary Banking Crisis 1973-1975, Its Causes and Courses, Basingstoke: Macmillan: 1982.

Roberts, A. Governmental adaptation to transparency rules, in Hood, C. and Heald, D. Transparency, The Key to Better Governance? Oxford: Oxford University Press: 2006.

Roberts, J. The possibilities of accountability." Accounting, Organizations and Society, 1991: 16(4): 355-368.

Sikka, P. and Willmott, H. Illuminating the State-Profession Relationship: Accountants Acting as Department of Trade and Industry Investigators, Critical Perspectives on Accounting, 1995: 6(4): 341-369.

Simmel, G. The Sociology of Georg Simmel, Free Press, Glencoe, Illinois: Free Press: 1950.

Sinclair A. The chameleon of accountability: forms and discourses, Accounting, Organisations and Society, 1995: 20(2/3):219-37.

Stewart, J.D. The Role of Information in Public Accountability, in A.G. Hopwwod and C.R. Tomkins (eds.), Issues in Public Sector Accounting, London: Philip Allan: 1984.

UK Africa All Party Parliamentary Group, The Other Side of the Coin: The UK and Corruption in Africa, London: AAPPG: 2006

UK Department of Trade and Industry, London and County Securities Group Limited, London: HMSO: 1976.

UK Department of Trade and Industry, London Capital Group, London: HMSO: 1977.

UK Department of Trade and Industry, Gilgate Holdings Limited, London: HMSO: 1981 (prepared by P.L Ainger and R.A Morrit).

UK Department of Trade and Industry, Ramor Investments Limited; Derriton Limited, London: HMSO: 1983 (prepared by H Carlisle QC and J Darby).

UK Department of Trade and Industry, Mirror Group Newspapers plc (two volumes), London: The Stationery Office: 2001. 
UK House of Commons Library, Research Paper 04/84: Freedom of Information Implementation, London: House of Commons: 2004

(http://www.parliament.uk/documents/commons/lib/research/rp2004/rp04-084.pdf).

UK House of Commons Trade and Industry Committee, Company Investigations, London: HMSO, 1990.

UK House of Commons Treasury and Civil Service Committee, Banking Supervision and BCCl: The Role of Local Authorities and Money Brokers, London: HMSO: 1991.

UK House of Commons Treasury and Civil Service Committee, Banking Supervision and BCCI: International and National Regulation, London: HMSO: 1992a.

UK House of Commons Treasury and Civil Service Committee, Banking Supervision and BCCl: The Response of Bank of England, London: HMSO: 1992b.

UK House of Commons Treasury and Civil Service Committee, Codes of Practice and Related Matters, London: HMSO: 1992c.

United States General Accounting Office, Foreign Bank: Initial Assessment of Certain BCCI Activities in the US, Washington DC: GAO: 1992.

United States Senate Permanent Subcommittee on Investigations, Money Laundering and Foreign Corruption: Enforcement and Effectiveness of The Patriot Act - Supplemental Staff Report on U.S. Accounts used By Augusto Pinochet, Washington DC: USGPO: 2005

United States Senate Foreign Relations Subcommittee on Narcotics, Terrorism and International Operations, The BCCl Affair: Hearings Part 1 - August 1, 2 and 8 1991, Washington DC: US Senate Committee on Foreign Affairs.

United States Senate Committee on Foreign Relations, The BCCl Affair: A Report to the Committee on Foreign Relations by Senator John Kerry and Senator Hank Brown, Washington: USGPO: 1992.

Vincent, D. The Culture of secrecy: Britain, 1832-1998, Oxford: Oxford University Press, 1998.

Weber, M. From Max Weber: Essays in Sociology, London: Routledge \& Kegan Paul: 1948 (translated and edited by H.H. Gerth and C. Wright Mills).

Weber, M. Economy and society; an outline of interpretive sociology, New York: Bedminster Press, 1968

Young, I.M. Inclusion and Democracy, Oxford: Oxford University Press: 2000. 